\title{
PROJECT PORTFOLIO OPTIMIZATION
}

\section{AS A PART OF STRATEGY IMPLEMENTATION PROCESS IN SMALL AND MEDIUM-SIZED ENTERPRISES: A METHODOLOGY OF THE SELECTION OF PROJECTS WITH THE AIM TO BALANCE STRATEGY, RISK AND PERFORMANCE}

\author{
Emil Vacík, Miroslav Špaček, Jiří Fotr, Lukáš Kracík
}

\section{Introduction}

Project Portfolio Management (PPM) deals with the coordination and control of multiple projects that pursue the same strategic goals and compete for the same resources, whereby managers prioritize among projects to achieve strategic benefits. PPM deals with simultaneously managing multiple projects and includes defining values, specifying priorities, solving conflicts between projects as well as defining organizational structure and the rules of its functions (Spradlin \& Kutoloski, 1999).

To provide maximum value to the organization, the portfolio must contain a balance of project types and risk levels as well as limit the number of projects to ensure that all projects can be resourced effectively (Killen, Hunt, \& Kleinschmidt, 2008). According to numerous studies, project portfolio management is currently applied in the practice of nearly all modern enterprises (Miguel, 2006).

In order to use PPM methodology successfully, it is necessary to form an effective portfolio configuration to control project prioritization and how set goals are fulfilled. It is also necessary to create a suitable organizational structure throughout the entire organization (Kunz, 2007). The main goal is to implement suitable projects at the correct time together with the optimum use of available resources. It is often asserted that the introduction of a PPM process is a key factor for project success (Wideman, 2005; Cooper, Edgett, \& Kleinschmidt, 2001).
Project management processes are included in international standards such as the PMBOK® (PMBOK, 2013), the PRINCE 2® (PRINCE2, 2017) and the IPMA $®$ (IPMA, 2015). These standards are internationally recognized and used. In this context, the German environment regularly uses the term 'multi-project management', which means the complex planning, coordination and control of multiple, mostly mutually dependent projects within one organisation / organisation unit. The definition of multi-project management is based on DIN 69901, which defines multiproject management as 'an organisational and procedural framework for managing more than one partial project' and is thus ranked into the systems of management. If more projects are to be implemented simultaneously within an organisation, the nature of multi-project management enables this expectation.

This subject has been addressed by many authors such as Aritua, Smith, and Bower (2009), Seidl (2011), Lomnitz (2004), Lukesch (2000), Steinle, Eßeling, and Mach (2010), Archer and Ghasemzadeh (1999) and many others. A survey of empirical studies is exemplified by Martinsuo (2013) or Verbano and Nosella (2010). Project portfolio development is one of the key phases of PPM. Its output is an optimized portfolio, the implementation of which contributes to the fulfilment of strategic goals and complies with the firm's strategy. To meet this demand, the portfolio development process must meet specific requirements in terms of the content and progress of its creation. 
During portfolio development the value of each single project, which represents key input information for portfolio optimization, must be taken in account. After performing a preliminary screening, unsuitable projects are eliminated from the portfolio. Managers of project portfolios must pay continuous attention to these characteristics even beyond the phase of portfolio selection. Project portfolios must be managed as periodic dynamic decisionmaking processes that encompass project evaluation, selection and prioritization in order to achieve a firm's strategic objectives and ensure projects are balanced without exceeding available resources or breaching set constraints (Ghasemzadeh \& Archer, 2000). Attention is paid to tools and techniques for portfolio evaluation and prioritization (Ringuest, Graves, \& Case, 1999), portfolio-oriented product development process management (Cooper, Edgett, \& Kleinschmidt, 2002), as well as resource management.

The aim of the PPM is to ensure that resources are allocated to projects in an optimum manner with respect to the entire portfolio (Engwall \& Jerbrant, 2003). Therefore, portfolio development represents the key phase of project portfolio management. Forming a balanced and effective portfolio is the initial step in transparent project implementation, which is necessary for meeting both the set of parameters of single projects and the portfolio. Finally, a well-developed project portfolio contributes significantly to the fulfilment of the firm's strategic goals. The use of strategic methods results in better alignment of projects in the portfolio with current business strategy.

Project portfolio optimization may considerably influence the future success of managing corporate strategy. According to the outputs of the study made by EY in the Czech and Slovak Republics (EY, 2013), the number of implemented internal projects that support company strategy is increasing. These findings support the hypothesis that organizations are more able to effectively manage their strategies by means of these projects. Along with the rising number of projects, their complexity and the demands upon their flexibility, the requirements concerning project management are also growing. While the notion of the project portfolio has already been commonly used in the Czech and Slovak Republics, PPM approaches have yet to be systematically or broadly implemented.
After a careful review of the literature and analysis of recent contributions, we find that many methods and models for project portfolio development and management have been formulated and reported in literature over the past years. These methods and models are often based on theoretical frameworks. Strengths and weaknesses may be highlighted in each of them. The present models are mainly based on fuzzy theory. For instance, four of them may be mentioned: (1) Distributionally robust fuzzy project portfolio optimization problem with interactive returns (Liu \& Liu, 2017); (2) New Optimization Model for Project Portfolio Selection under Interval-Valued Fuzzy Environment (Mohagheghi, Mousavi, \& Vahdani, 2015); (3) A Study on Project Portfolio Models with Skewness Risk and Staffing, which proposes a project portfolio model with staffing based on credibility measure theory and fuzzy theory under uncertain circumstances $(\mathrm{Xu}$, Liu, \& Li, 2017); and (4) R\&D project evaluation and project portfolio selection by a new interval type-2 fuzzy optimization approach (Mohagheghi, Mousavi, Vahdani, \& Shahriari, 2017).

These sources of literature mostly fail to include methods for implementing the principles of project portfolio design and incorporate it into the routine practice of SMEs. This finding was fundamental to the further research described in this paper. Although financial metrics are part of most PPM processes, some literature indicates that financial methods may not be the most beneficial portfolio method to use. Strategic methods and portfolio maps have the most positive influence on portfolio performance. On the other hand, financial methods correlate with positive performance on only one PPM metric and do not lead to higher values of the projects in the portfolio as expected. (Killen, Hunt, \& Kleinschmidt, 2008). The process of the preparation of effective project portfolios by means of the use of available software tools to facilitate risk-based managerial investment decision-making in SMEs has not yet been described in any scientific literature.

It is well known that there is a longstanding difference between the complex and sophisticated tools developed by academics and the simple techniques requested by management (Fahrni \& Späting, 1990; Poh, Ang, \& Bai, 2001).

This paper aims to bridge this gap by offering methodology based on applying the computer 
supported stochastic optimization model, which uses the available software tool OptQuest. This methodology makes it possible to develop and evaluate multiple project portfolios and thus prepare a quality basis for managerial investment decision making. The goal of this paper is to develop the methodology of project portfolio optimization, which could support strategic goal fulfilment and verify benefits of using such methodology in the practice of the Small and Medium-Sized Enterprises (SMEs) segment. The other benefit is the flexibility of the development and assessment of portfolios under the changing conditions of the business environment.

It is up to company management to decide whether to place more emphasis on the value of projects, which is determined by multicriteria evaluation or expected Net Present Value (NPV) of a portfolio. Increasing the efficiency of the portfolio process requires gathering information concerning the minimum number of elements needed to capture the essential decision dynamics required by managers (Mathews, 2009). The objective is to ensure portfolio performance enhancement.

The case study, based on a selected company, represents a more complex approach to the application of the methodology on how to develop optimum project portfolio with respect to existing constraints and performance goals. The case study proved that this methodology may be feasible in the SME segment.

\section{Theoretical Background}

Contemporary firms often implement strategy by means of project portfolios. Selection, planning, management and monitoring of project portfolios in an organisation or its unit is the subject of PPM. Regarding the set strategic goals of the organisation, the aim of PPM is to ensure the selection of effective projects and simultaneously respect the efficient use of resources (technological, financial, personnel, informational and organisational). Conformity between these formulated strategic goals and the investment policy of an organisation is pursued in this manner.

The task of project portfolio evaluation and choice of an effective portfolio has been dealt with by many other authors. Seidl (2011) applies a four-level filter for evaluation, optimization and selection of projects that enables formal control of the projects, their evaluation according to set criteria, identification of mutual relationships and decisions concerning their implementation. Lukesch (2000) assumes the establishment of benefits and risks of partial projects. Emphasis is put on a value analysis based on Free Cash Flow. When defining the impact of risk, even the value of options is respected. Lomnitz (2004) prioritizes the systematic selection of projects based on gradual evaluation of 'the project ideas' according to four basic evaluation criteria - conformity of projects with strategy, level of project risk, disposable capacities and the necessary know-how. Kunz (2007) recommends that pre-screening projects go into the selection process based on several main criteria. Kock and Gemünden (2016) studied the quality of innovation project portfolio development and the ability to quickly adapt the portfolio. Aas, Breunig, and Hydle (2017) focused their effort on practices of portfolio management in the field of new service development.

Effective PPM leads to: (1) effective allocation/ reallocation of resources, (2) reinforcement of competitiveness within the firm, (3) balanced portfolios that include short-term and long-term projects that cover high-risk and low-risk projects, (4) possible suspension or termination of ineffective members within the project portfolio, (5) use of synergies between projects, (6) development of skills and competencies, (7) unification of terminology, reporting and communication when managing projects and (8) searching for new opportunities for effective projects within investment limits (Fotr \& Souček, 2015).

Holistic, strategy-based portfolio management methodologies and practices suggest that portfolio-level decisions should be made at the single-project level or through development processes. These single-project and portfolio management practices are linked to company level performance indicators (Cooper et al., 2004). Some studies provide initial evidence on a potential link between singleproject management and portfolio management efficiency (De Reyk et al., 2005). On the other hand, projects should attempt to enhance their autonomy and optimize their resource use in pursuing their own performance and business goals (Martinsuo \& Lehtonen, 2007).

The success of an accepted strategy often depends on its flexibility and capability to switch over to more useful strategic alternatives. The important parameter of performance beside its economic aspects, such as NPV, is a portfolio 
value based on the multi-criteria evaluation of projects. Managerial decisions concerning a firm's future strategy must respect the circumstances of entrepreneurial development that are usually formulated within strategic scenarios (Fotr et al., 2010; 2015). The task of project portfolio management is then to formulate such portfolio configurations that reflect all its main strategic parameters and are feasible for implementation within the disposable potential of the firm. In some studies (Brester, Ryzhikov, \& Semenkin, 2017) the project portfolio decision-making problem was even reduced to a $0-1$ knapsack constrained multi-objective optimization problem.

Companies are always required to implement mandatory conditions such as environmental impact restrictions and work safety enhancement. Otherwise, the company is penalized or conditionally closed down. This should be reviewed separately from the project in question. On the other hand, mathematical programming has a scientific basis and therefore either replaces or complements intuitive approaches in developing an optimum investment portfolio. Its limitation lies in the necessary qualification of investment analysts to cope with various programming techniques.

In industrial practice, it is sometimes difficult to persuade top managers of the substance and reasons behind this scientific approach, which may seem slightly obscure to them. There is evidence that portfolio managers are often not properly informed and their criteria and routines may not solve multi-project problems as expected (Engwall \& Jerbrant, 2003). Decision making on project and portfolio selection is less planned and rational and often more political (Sanwal, 2007) and path-dependent than normative models would suggest. Some authors showed evidence (Aaltonen, 2010) of a path of dependence leading from past decisions to future decisions in portfolio management and the evolution of the portfolio based on both planned and co-selected project features. Possible explanations include the lack of awareness of practice (i.e. what managers actually do) and context (i.e. what are unique conditions in which the project portfolio is being managed) (Martinsuo, 2013).

\section{Research Questions and Methodology}

After reviewing current research and literature, it seems the main goals of the PPM process are generally agreed to be: (a) to maximise the financial value of the portfolio, (b) to ensure balance among projects by limiting their number to fit organisational capacity, and (c) to ensure that the portfolio reflects the company strategy (Cooper \& Edgett, 2003; Dawidson, 2004). There are many PPM methods used to assist with strategic decision-making, risk evaluation, and resource allocation for both new and ongoing projects. Many papers concerning project portfolio development and optimization were directed to specific fields of application, such as e.g.: (1) power engineering (Pérez, Watts, \& Flores, 2018; Qiang, 2017), (2) water supply (Wu, Dandy, Maier, Maheepala, Marchi, \& Mirza, 2017), (3) railway construction (Joubert \& Pretorius, 2017), (4) toll road forecasts (Shah \& Jammalamadaka, 2017), and (5) oil and gas industries (Korotin, Popov, Tolokonsky, Islamov, \& Ulchenkov, 2017). To complement previous studies, a firm acting in the generic pharmaceutical industry was chosen as a typical representative of the SME segment.

To ensure a correctly optimised project portfolio, managers must consider the different phases, progress, interdependencies, conflicts and characteristics of their projects (Verbano \& Nosella, 2010). The best metrics applicable for one development activity may not apply to others (Hauser \& Zettelmeyer, 1997). Some early PPM methods attempted to develop similar solutions through mathematical models and optimization techniques; however, these are not widely used due to the complex nature of the environment (Coldrick, Longhurst, Ivey, \& Hannis, 2005). Sometimes the project selection process is supported by both specific software and the role of external experts, who make an important contribution to identify the most suitable projects (Yong-Hong et al., 2008).

Contextual interviews were conducted with top, middle and first line managers and/or experts. In total, 23 interviews were conducted in companies operating in the pharmacy, chemistry, machinery and construction business. Such number of interviews is in consonance with Creswell's findings. Creswell considers 20-30 interviews sufficient (Creswell, 2007). Aas et al. (2017) conducted 52 in-depth interviews with managers and employees involved in the area of new service development. The interview was completed the moment no new findings about the topic could be objectively obtained. The usual duration of each interview varied from 
70 to 80 minutes. The interviews were usually conducted by some of the authors of the paper, which ensured an acceptable professional level of the interview. The aim of these interviews was to examine (i) the scope of the active portfolio, (ii) the links between the portfolio and corporate strategy, (iii) fulfilment of portfolio performance parameters (i.e. goals, deadlines and budget within predefined constraints), (iv) the risk exposure impact on project portfolio development, and ( $v$ ) the usual method of the decision-making process concerning project portfolio development.

Ethnographic research performed in SMEs made it possible to formulate two hypotheses: (1) effective project portfolio development is a necessary precondition for the fulfilment of strategic goals and (2) effective project portfolio development is a necessary precondition for meeting the performance parameters of such a portfolio. That is why three basic research questions were raised: (1) What changes have to be made in the SME environment to execute investment strategies by using Project Portfolio Management? (2) How can the project portfolio parameters be changed depending on risk exposure change? (3) How can the project portfolios that are developed via this method positively influence the managerial decision process?

The following analysis is focused on determining a portfolio efficient frontier, which is determined by the introduction of variable limitations to portfolio risk. The models handle multi-criteria evaluations and respect portfolio risks. As a tool supporting portfolio optimization, we used the OptQuest software application. This program is part of the Crystal Ball system that enables a Monte Carlo simulation (Fotr \& Hnilica, 2014).

For the purpose of this research, the set of input data necessary for project portfolio optimization involves the following parameters: (1) Value as a result of multi-criteria evaluation of the project. The criteria used for project evaluation were more extensive. In addition, value beside NPV includes other criteria such as compliance with the corporate strategy, intensity of contribution to the accomplishment of the company's strategic goals, product competitive advantage, support of key competencies and market appeal. In the pre-defined criteria for the evaluation of projects, NPV was ranked as the primary criterion. (2) Probability distribution of NPV as determined by the Monte Carlo simulation. This probability distribution must be approximated by the most convenient type of theoretical probability distribution because the project portfolio optimization by means of OptQuest requires such input data conversion (the most frequent distributions were beta and sometimes normal distribution). (3) The probability distribution of investment costs was determined on an expert basis as subjective probability distribution. To some extent flexible beta PERT distribution was chosen as the most appropriate distribution. This distribution is usually asymmetric with positive skewness (an inclination towards higher values of investment costs which indicates the danger of exceeding planned investment costs). Based on input parameters of probability distribution (typically lower limit, modus and upper limit), expected values were generated along with standard deviations of investment costs for each project. (4) A headcount necessary for each investment project. (5) Upon optimization, both the statistic dependence between investment costs and NPV of each project and the statistic dependence between NPVs of individual projects were evaluated. In both cases, this was based on an expert estimation of correlation coefficients.

\section{Research and Its Results}

The research was performed using the casestudy model in a company. PharmaComm, Ltd. is a privately owned mid-size Czech generic pharmaceutical company (105 employees, sales approx. 150M CZK, assets/liabilities over $150 \mathrm{M}$ CZK) focused on the production of active pharmaceutical ingredients (API). The company has developed a strategic plan, part of which was an extensive research and development program. This company was selected because of its ability to manage a wide portfolio of investment innovative projects that were a condition for the company's future strategic development. The successful implementation of their strategic plan was contingent upon meeting several key success factors such as availability of capital, employees with required competency profiles, establishment of a company information and knowledge base, etc. In conjunction with strategy development, the company had to solve a problem concerning the optimization of a product portfolio that would maximize shareholder value at an acceptable risk level and respect all pre-defined constraints. 
The production of active pharmaceutical ingredients (API) is a branch of business where specialized chemical and pharmaceutical businesses overlap. API business combines strict regulatory requirements that are typical for the pharma business with technical demands that are pertinent to specialized chemical businesses. The case study deals with investment project portfolio optimization in a mid-size Czech pharmaceutical company that operates a generic API business.

Both the current and proposed product portfolio is aimed at the production of very complex hormone-based generic drugs. The company faces several problems regarding the operation of several innovation projects in parallel. The first is a restricted investment budget, preferably to be used for the purchase of new facilities. The second represents constraints regarding available inhouse human resources. In order to develop technology and testing methods, but also to validate processes and testing methods, skilled or at least technically knowledgeable staff is necessary. The interviewees included company investment managers who were purposefully involved in the research as well as directors and external experts originating from professional associations such as the Chemical Industry Association, the Association of Small and Medium-Sized Enterprises and Crafts CZ etc. The criteria for the selection of persons for ethnographic research were the following: deep involvement in company strategic management, experience in project portfolio management, skills in risk management and resource constraints management.

These constraints are nearly insurmountable, as obtaining additional financing through increased debt is either risky or too costly for the company. Similarly, hiring additional staff which possesses the required skills in the chemical and pharmaceutical development of special APIs is out of the question. In general, there is a long-lasting shortage of technically educated specialists in the Czech labour market and special inhouse training in pharmaceutical development capabilities is painstaking and time consuming. As a matter of practice, the education and training of pharmaceutical specialists takes at least one year and usually more.

Another point worth discussion is the management of an innovation products portfolio from the marketing point of view. The company is required by its customers to offer a balanced product portfolio regardless of economic effectiveness. As an example, both latanoprost and travoprost are aimed at glaucoma treatment, but the tolerability of either drug among patients varies. Some patients better tolerate latanoprost while others travoprost. For this reason, these drugs cannot be regarded as substitutes and customers want the producer to offer some proportion of both drugs, both of which are to be included in portfolio optimization. This strategy is endorsed by the owner because he considers a balanced product portfolio to be a meaningful provision for risk mitigation.

Management of innovation projects in pharma is a complex matter. R\&D in pharma tackles the development of new (often termed 'innovative') drugs along with 'generic' brands. The former represents the costly development of quite new drugs whose therapeutic effects are based on new principles while the latter refers to generic copies of drugs whose patent protection has already expired. Even though the generic drug business produces products whose structure is known but not easily imitated in the exact form, properties and stability of the original drugs. Companies use various technologies to produce products that meet requirements for both quality and economy (Gassmann \& Reepmeyer, 2005).

\subsection{Characteristics of the Initial Set of Projects}

The company developed eighteen research projects, each of which was considered for extending its current product portfolio. The following parameters were set for each project: (1) value as a result of multi-criteria evaluation (weighed summation, qualitative criteria using point scale, quantitative linear approximation); (2) probability distribution of NPV and its parameters (expected value and standard deviation) (3) expert estimation of subjective probability distribution of investment costs and its parameters (expected value and standard deviation); (4) demand for technical and operator staff. Each project was executed in several variants that reflected different scenarios of environment development and different strategic variants prepared by the company. During preliminary screening the variants with negative NPV were ruled out of 
the portfolio because their implementation was out of the question.

Each project was characterized by a different level of risk. Some projects like alprostadil-alfadex or dinoprost made use of existing technologies and represented only an extension of current technological procedures. Their risks were relatively low (measured by std. deviation). Additionally, chemical specialties projects were not high risk since their technical know-how and testing methods were transferrable from the parent company.
The balance of the project listed innovation projects that were considered significantly riskier. These risks were mostly of a technical and market character. Moreover, the risks of the project varied even for individual reasons. This was because their varied production scale as well as extended customer portfolios posed different levels of risk for each variant of the project. The set of projects is shown in Tab. 1.

Tab. 2 shows disposable resource volumes including capital budget and headcounts of technicians and operators. Tab. 2 also includes

\section{Tab. 1: Key parameters of project portfolio optimization in the pharma branch}

\begin{tabular}{|c|c|c|c|c|c|c|c|c|c|}
\hline 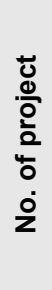 & 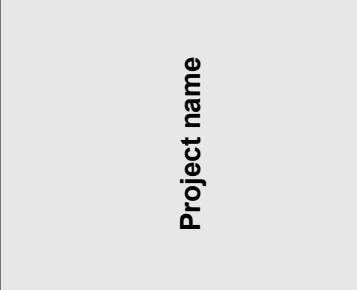 & $\frac{\frac{0}{J}}{\frac{\pi}{\pi}}$ & $\underset{\text { 親 }}{S}$ & 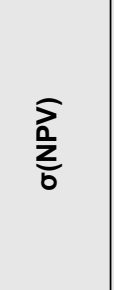 & $\stackrel{\widehat{U}}{\underline{U}}$ & $\frac{0}{0}$ & 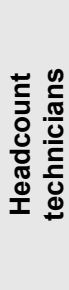 & 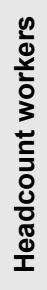 & 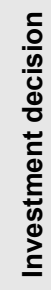 \\
\hline 1 & alprostadil alfadex - var. A & 28 & 12,847 & 580 & 1,753 & 150 & 2 & 1 & $0 / 1$ \\
\hline 2 & alprostadil alfadex - var. B & 35 & 27,880 & 1,503 & 3,479 & 250 & 3 & 1 & $0 / 1$ \\
\hline 3 & bimatoprost - var. B & 55 & 99,233 & 15,492 & 15,168 & 1,603 & 3 & 4 & $0 / 1$ \\
\hline 4 & bimatoprost - var. C & 65 & 226,762 & 39,099 & 51,546 & 4,591 & 5 & 15 & $0 / 1$ \\
\hline 5 & epoprostenol - var. A & 25 & 6,213 & 793 & 4,310 & 446 & 2 & 2 & $0 / 1$ \\
\hline 6 & epoprostenol - var. B & 55 & 27,743 & 3,894 & 10,531 & 960 & 3 & 2 & $0 / 1$ \\
\hline 7 & epoprostenol - var. C & 70 & 80,919 & 10,090 & 10,827 & 1,020 & 4 & 4 & $0 / 1$ \\
\hline 8 & epoprostenol - var. D & 90 & 177,396 & 22,208 & 34,478 & 2,940 & 15 & 8 & $0 / 1$ \\
\hline 9 & chemical specialties - var. A & 60 & 56,235 & 2,897 & 11,394 & 469 & 19 & 1 & $0 / 1$ \\
\hline 10 & chemical specialties - var. B & 45 & 33,048 & 1,856 & 8,123 & 413 & 14 & 1 & $0 / 1$ \\
\hline 11 & chemical specialties - var. C & 25 & 16,115 & 780 & 10,966 & 586 & 10 & 1 & $0 / 1$ \\
\hline 12 & iloprost - var. A & 60 & 26,269 & 3,756 & 5,302 & 209 & 2 & 3 & $0 / 1$ \\
\hline 13 & iloprost - var. B & 74 & 55,827 & 8,276 & 11,326 & 510 & 2 & 5 & $0 / 1$ \\
\hline 14 & latanoprost - var. B & 80 & 44,680 & 8,249 & 15,541 & 1,908 & 5 & 4 & $0 / 1$ \\
\hline 15 & Travoprost - var. A & 70 & 20,621 & 2,452 & 7,094 & 858 & 3 & 3 & $0 / 1$ \\
\hline 16 & dinoprost - var. A & 42 & 4,007 & 291 & 4,972 & 515 & 2 & 4 & $0 / 1$ \\
\hline 17 & dinoprost - var. B & 60 & 19,094 & 1,577 & 17,158 & 1,829 & 4 & 7 & $0 / 1$ \\
\hline 18 & unoprostone - var. C & 28 & 3,473 & 550 & 3,704 & 475 & 2 & 2 & $0 / 1$ \\
\hline
\end{tabular}

Source: own

Note: $E(N P V)=$ expected value of NPV (thous. CZK); $\sigma(N P V)=$ standard deviation of NPV (thous. CZK); E(IC) = expected value of investment cost (thous. CZK); $\boldsymbol{\sigma}(\mathbf{I C})=$ standard deviation of investment cost (thous. CZK). 
Tab. 2: Available values of resources and their consumption

\begin{tabular}{l|c|c|c}
\multirow{2}{*}{ Quantity } & \multicolumn{3}{|c}{ Resources } \\
\cline { 2 - 4 } & $\begin{array}{c}\text { Capital budget } \\
\text { (thous. CZK) }\end{array}$ & $\begin{array}{c}\text { Headcount } \\
\text { technicians }\end{array}$ & $\begin{array}{c}\text { Headcount } \\
\text { operators }\end{array}$ \\
\hline Available value & 145,000 & 48 & 36 \\
\hline Requirement & 227,673 & 100 & 68 \\
\hline Exceeding value & 82,673 & 52 & 32 \\
\hline
\end{tabular}

Source: own

resource volumes in the event that we would like to realize all eighteen projects. The exceeding value indicates the volume of additional resources, which needed to be obtained for the realization of all the projects.

\subsection{Project Portfolio Optimization}

When optimizing, it is necessary to pay attention to three constraints in resources. The goal of optimization is to develop a portfolio that maximizes its $E(N P V)$ upon given constraints (investment budget, technician and operator headcounts). Resources and their constraints are specified in Tab. 2.

Tab. 1 shows key input data to be further processed during optimization. Eighteen projects were subjected to optimisation, some of which were submitted in several strategic variants. In agreement with the logic of investment decision-making, each project can be selected into a portfolio in only a single variant. Moreover, the company insisted on including two projects (latanoprost and travoprost) into the portfolio since these projects are in accord with their global strategy.

The results of the optimization are summarized in Tab. 3. Finally, seven projects were included in the optimum portfolio.

Stochastic optimization of the investment project portfolio resulted in a composition of the entire investment portfolio which has E(NPV) of 546,514 thousand CZK. The risk of optimal portfolio expressed by standard deviation is 45,761 thousand CZK. In agreement with the assumptions, no variant (or at most one variant) of the project could be included in the project portfolio. Two mandatory projects (14 and 15) which were required by the company to be represented in the portfolio are included.

As far as resource constraints are concerned, the investment budget to be allocated for the implementation of the optimal portfolio amounts to 125,563 thousand CZK. Thus, there remains a financial reserve amounting to 19,437 thousand CZK to cover unexpected excesses in the capital budget or contingency measures. $E(I C)$ represents the expected value of investment costs that can be exceeded.

As for human resources constraints, specified in terms of technicians and workers to be available, the optimized portfolio operates with 47 technicians out of a total of 48 and 35 operators out of a total of 36 . There is also little reserve in staffing projects (one redundant employee in both technicians and workers group) to be selected for the portfolio that can be used as a contingency measure. The entire value of the project portfolio selected was 445 . Apart from portfolio E(NPV), maximization of value was not chosen as the key criterion for portfolio selection since it is not a stochastic value. It served as a supportive criterion.

Tab. 3: Summary of optimum portfolio parameters

\begin{tabular}{|l|c|c|c|c|c|c} 
Portfolio structure & Value & $\begin{array}{c}\text { E(NPV) } \\
\text { (thous. } \\
\text { CZK) }\end{array}$ & $\begin{array}{c}\sigma(N P V) \\
\text { (thous. } \\
\text { CZK) }\end{array}$ & $\begin{array}{c}\mathrm{E}(\mathrm{IC}) \\
\text { (thous. } \\
\text { CZK) }\end{array}$ & $\begin{array}{c}\text { Headcount } \\
\text { technici- } \\
\text { ans }\end{array}$ & $\begin{array}{c}\text { Headcount } \\
\text { operators }\end{array}$ \\
\hline $2 ; 4 ; 8 ; 10 ; 12 ; 14 ; 15$ & 445 & 546,514 & 45,761 & 125,563 & 47 & 35 \\
\hline
\end{tabular}




\section{Fig. 1: Probability distribution of project portfolio NPV source}

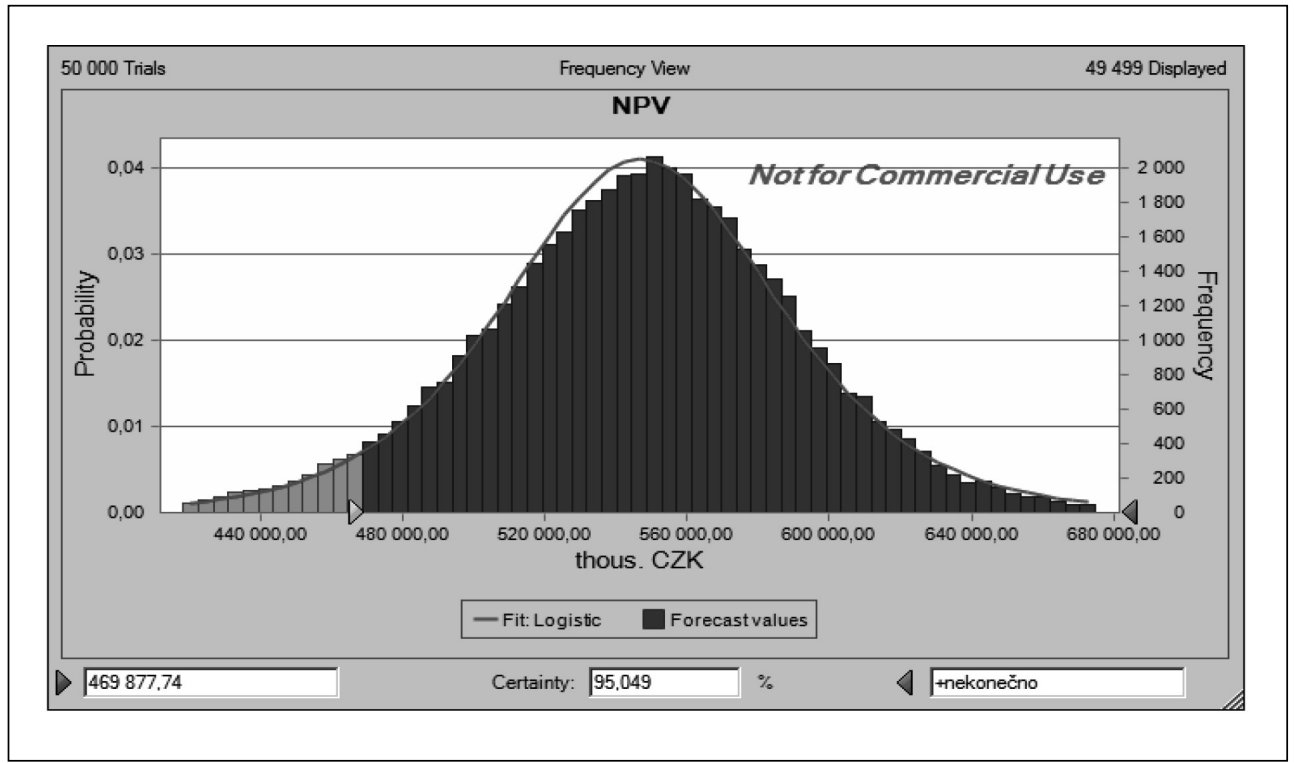

Source: own

If the company wants to achieve a portfolio with higher value, the inclusion of the requirement for the achievement of a certain bottom-limit value of the portfolio (e.g. 475) into the set of constraints is necessary. Additional increase in value results in a decrease in $E(N P V)$. During the next investment decision making process, management should trade-off between value and E(NPV).

Probability distribution of project portfolio NPV is shown in Fig. 1. Theoretical distribution, which fits well in calculated distribution, is logistic.

From a risks perspective, there is a $95 \%$ certainty that the NPV of the optimal project portfolio will be greater than 470,000 thousand CZK (see Fig. 1).

Another task, which was dealt with during optimization, was finding an efficient frontier of the portfolio in light of its risk. An efficient frontier was determined by maximization of $E(N P V)$ within the portfolio by gradually increasing the upper limit of its risk measured by standard deviation. Despite the fact that the standard deviation of the optimal portfolio is 45,761 thousand, the lower limit of risk was selected in terms of the standard deviation of 25,000 thousand and the upper limit up to 60,000 thousand. During the optimization process, the first efficient portfolio EP1 with E(NPV) 398,168 thousand CZK, standard deviation of 22,638 and with the value of 532 (see Tab. 4) was determined. In the second optimization the upper limit of risk 30,000 thousand was determined. The next six optimizations continued by gradually increasing the upper limit of risk by 5 thousand up to 60,000 thousand. The results of efficient frontier calculation are shown in Fig. 2 and Tab. 4.

It became evident that $E(N P V)$ rose in consonance with increasing the upper limit of risk (expressed as std. deviation). It is apparent that this dependency is not proportionate. The change in risk level did not always result in the generation of a new portfolio with higher $\mathrm{E}(\mathrm{NPV})$. Despite eight consecutive changes made in portfolio risk, only four portfolios were developed. (EP1, EP2=EP3=EP4, EP5, EP6=EP7=EP8). Such a situation may come into effect when no better portfolio can be developed.

Using stochastic optimization for a project portfolio is worth considering even for Small 


\section{Ekonomika a management}

Fig. 2: Efficient frontier determination

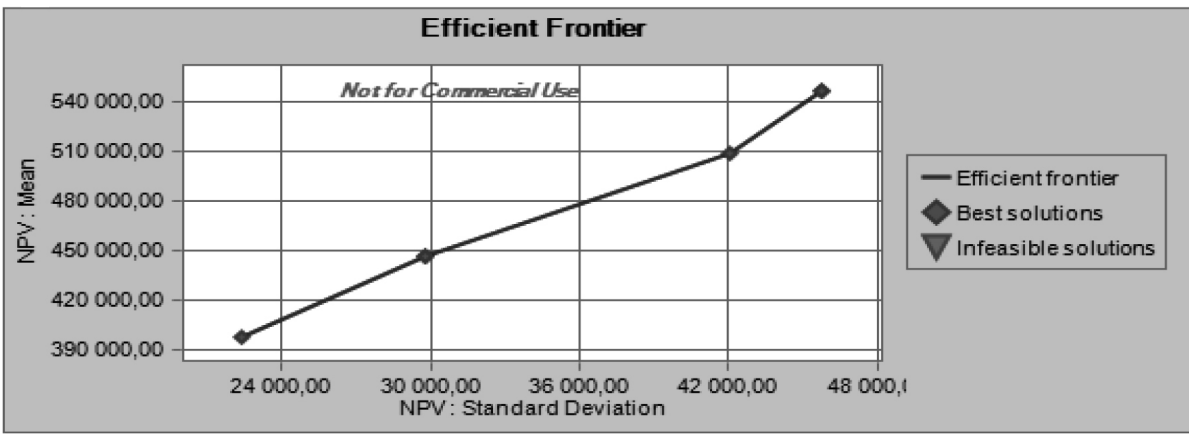

Source: own

\section{Tab. 4: Efficient frontier}

\begin{tabular}{l|l|l|l|l|l|l|l}
$\begin{array}{l}\text { Effective } \\
\text { portfolio }\end{array}$ & \multicolumn{1}{|c|}{ Portfolio structure } & E(NPV) & $\sigma(N P V)$ & Value & E(IC) & $\begin{array}{c}\text { Head- } \\
\text { count } \\
\text { techni- } \\
\text { cians }\end{array}$ & $\begin{array}{c}\text { Head- } \\
\text { count } \\
\text { opera- } \\
\text { tors }\end{array}$ \\
\hline EP1 & $2 ; 3 ; 7 ; 9 ; 13 ; 14 ; 15 ; 17 ; 18$ & 398,168 & 22,638 & 532 & 95,691 & 45 & 31 \\
\hline EP2 & $2 ; 3 ; 8 ; 10 ; 13 ; 14 ; 15 ; 16$ & 446,296 & 29,746 & 491 & 100,181 & 47 & 30 \\
\hline EP3 & $2 ; 3 ; 8 ; 10 ; 13 ; 14 ; 15 ; 16$ & 446,296 & 29,746 & 491 & 100,181 & 47 & 30 \\
\hline EP4 & $2 ; 3 ; 8 ; 10 ; 13 ; 14 ; 15 ; 16$ & 446,296 & 29,746 & 491 & 100,181 & 47 & 30 \\
\hline EP5 & $2 ; 4 ; 7 ; 9 ; 13 ; 14 ; 15 ; 18$ & 509,420 & 42,039 & 482 & 114,910 & 43 & 35 \\
\hline EP6 & $2 ; 4 ; 8 ; 10 ; 12 ; 14 ; 15$ & 546,514 & 45,762 & 445 & 125,563 & 47 & 35 \\
\hline EP7 & $2 ; 4 ; 8 ; 10 ; 12 ; 14 ; 15$ & 546,514 & 45,762 & 445 & 125,563 & 47 & 35 \\
\hline EP8 & $2 ; 4 ; 8 ; 10 ; 12 ; 14 ; 15$ & 546,514 & 45,762 & 445 & 125,563 & 47 & 35 \\
\hline
\end{tabular}

Source: own

and Medium-Sized Enterprises. It helps investment analysts analyse risks of bundles of projects that are candidates for investment portfolios upon pre-defined constraints. This approach enables interconnecting investment decision-making with scenario approaches and promotes investment decision-making to a highly valued strategic method. Using stochastic portfolio optimization facilitates the optimum selection of project portfolios upon a variety of constraints that may be project funding and staffing on one hand and operating project variants or mandatory projects on the other. One of the results of the optimization represents the probability distribution of NPV of the optimal portfolio (see Fig. 2), which provides 
both company management and owners with a contribution toward company value engineering. Another important outcome of project optimization is portfolio efficient frontier calculation, which describes the dependency between the expected NPV of the portfolio and the risks that are expressed by means of standard deviation of the portfolio. Such a calculation offers a powerful tool to managers, enabling them to properly balance gains and risk and thus boost the quality of their decisionmaking.

The chosen firm was a complex one, with limited resources and project content. It was not possible to make large changes in the firm's infrastructure to overcome resource constraints. That is why, regarding acceptable risk, the profitability index value was considered in portfolio selection. The profitability index was calculated as per formula (1):

$$
\text { Profitability index }=\frac{\mathrm{E}(\mathrm{NPV})}{\mathrm{E}(\mathrm{IC})}
$$

The profitability index of the portfolio EP5 was 4.43 while the profitability index of the portfolios set EP6-EP8 was 4.37. Therefore portfolio EP5 was preferred for implementation. The value of the portfolio EP5 (482) is also higher than the values of the portfolio sets EP6EP8 (445). In this case the set goals were met and the modelling of portfolios contributed to a performance increase in the firm.

\section{Discussion}

PPM includes elements of operational and strategic decision-making. At the strategic level, this includes portfolio composition and the choice of the relevant priorities. The following parameters belong to the main objectives of project portfolio management:

(1) Selecting projects that yield the highest benefits, (2) prioritizing projects within the portfolio, (3) managing risks within the portfolio and (4) respecting pre-set resource limitations. It is clear why strategic methods are often used in the initial decision-making phase of project selection. Then one or more various techniques, such as mathematical programming, are applied in the phases that follow (Cooper et al., 2001).

The selected firm is active in the highly sophisticated pharmaceutical industry, which possesses limited resources of specialists whose skills are not easily gained within the time available for project portfolio restructuring.
The preferences of partial projects must be considered as early as the basic portfolio is being assembled. The selection of an efficient portfolio (EP5) was essential for the competitive advantage and value creation of the firm. Given the limited resources, the flexibility of innovation project portfolios was inevitable for strategy implementation.

Strategic priorities are strongly influenced by the development of environmental requirements, which is why management must have deep experience in strategic management. Following the suggestions of the European Industrial Research Management Institute (EIRMA, 1995), costs mainly concern the time staff must spend in implementing the chosen method and selecting projects. Choices should be geared toward the techniques that best meet decision-maker requirements. Strategic aspects are difficult to monetise (Lawson, Longhurst, \& Ivey, 2006; Poh et al., 2001).

The software used is suitable for both research purposes and practical use in SME companies. A certain shortcoming of the software is that it does not enable portfolio optimization with deterministic criteria (e.g. in our case study optimization of portfolio value). The results are easy to interpret and represent sufficient background for making managerial decisions of such importance. However, separate managerial decisions cannot be made only on the basis of computer simulations and optimization. It is worth mentioning that additional criteria, mostly of a qualitative character, should be taken into account. It was proven that the OptQuest software tool, which was used for the research, can be mastered by company management as well. Nevertheless, determining input parameters is demanding in terms of expert knowledge. Either internal or external expert consultation regarding portfolio development is worth considering.

The other requirements for successful implementation of a chosen project portfolio are the capabilities of project manager staffing. Changes in portfolio may be necessary to optimise the portfolio and satisfy stakeholders. On the other hand, they alter the logic of the project portfolio management system based on political and emotional decision processes rather than more rational ones (Christiansen \& Varnes, 2008).

Although the set of projects integrated into a project portfolio may be correct, the 
fulfilment of project goals may still fail (ERNST \& YOUNG, 2013; Vacík \& Kracík, 2015). This means that paying attention to both phases of project portfolio development, selection and management is paramount.

\section{Conclusion}

In accordance with the goal of this paper, the presented methodology was applied in SMEs. The applied methodology became a principal process innovation in managing company investments. This methodology, which was executed in cooperation with the firm's management, provided managers with the support to clearly and persuasively explain their reasons for making decisions to stakeholders. Quantitative outputs of the simulation were later adopted by the company management as internal strategic goals for portfolio management. The methodology itself was evaluated by the company's management as a helpful tool that can improve strategic management in the firm.

Based on the research, the authors were able to evaluate whether the application of such methods was useful and/or if there were underlying assumptions necessary for the standard managerial use of this tool. This case study included all the combined complexity and difficulties related to project portfolio development. The outputs of this paper present the results of two project portfolio optimization problems: (1) maximization of the portfolio NPV and (2) setting an effective portfolio frontier. The selection of projects for portfolios was pre-determined by two constraints - financial budgeting and employees with appropriate competency profiles. As the input data for project portfolio optimization, multi-criteria values, probability distributions of NPV, investment costs for every project and disposable capital budget and headcount were determined.

The outputs of conducted interviews yielded valuable information confirming the necessity of the use of methodology that could improve project portfolio management in SMEs. According to the content of answers, it can be concluded that:

(i) Over two thirds of respondents confirmed that the SMEs organizations operated 3-10 projects within each project portfolio. Seven respondents did not manage their projects by means of project portfolio tools and they managed only particular projects separately. (ii) More than half of respondents implemented the strategies with the support of project approaches. Project portfolio management became a valuable tool of strategic management mainly in innovative companies implementing innovative projects.

(iii) In terms of the fulfilment of performance parameters, most respondents confirmed that almost $15 \%$ of the projects exceeded the budget by $20-50 \%$. Over $30 \%$ of the projects exceeded the set deadline by more than $20 \%$. In terms of deadline and budget, only every second project was completed. The following facts are considered to be the most frequent causes for failure in successfully implementing the projects: (a) change in the extent of the project resulting from the incorrect definition of the time frame; (b) insufficient staffing of the project and coordination of the project team; (c) insufficient support from top management; (d) impact of the changes in the external environment.

(iiii) Only $4 \%$ of respondents used some advanced methodologies for risk measurement such as variance or standard deviation. The risk exposure was mostly estimated by qualitative two-factorial analysis of profitability vs. probability of success.

(iiiii) A standard decision-making process about project portfolio development was preferably based on economic criteria such as Return of Investment (ROI) or Net Present Value (NPV). Risk exposure was treated by means of discount rate adjustment according to the shareholder's demand. As for non-financial criteria, resource constraints were the most respected.

After carefully reviewing the outputs of our research, we found it was possible to answer the following research questions:

(1) The conducted interviews and presented case study proved it was possible to execute investment strategies using PPM in the environment of SMEs. Changes in the SMEs structure were necessary only to a moderate extent. It is advisable to hire an expert with a mastery of software modelling. The conditions under which the strategic goals were set must be fulfilled with respect to existing constraints on resources. All projects included in developed portfolios were sufficiently transparent to support the execution of the formulated strategy. The tools of strategic management appear to have a strong influence on both portfolio configuration and its future performance. 
(2) Standard software systems make it possible to carry out the development of optimum project portfolio configuration with respect to given performance goals, risk exposure and defined constraints. Because of the change in portfolio risk exposure, both portfolio performance parameters and portfolio configuration were changed. It is within the scope of company management authority to reflect and evaluate risk exposure upon making a final decision. All these processes can be standardised as routine business activities of the company.

(3) Project portfolio optimization and analysis result in important input information for top management investment decisions in which top management must consider additional, usually qualitative information (which is involved in value parameters). These facts may or may not be reflected in optimization models. The output of the software simulation with risk evaluation was very helpful for decision-making bodies of the company. The information that was presented served as a strong argument for discussions with stakeholders when defending a chosen solution.

The methodology was applied in a real Czech organization that is narrowly focused on R\&D. The strategy was implemented using the project portfolio approach. This approach was typical for the pharmaceutical industry. In the pharmaceutical industry, companies usually operated above the average number of projects in parallel. This was the case in the chosen company, which operated 18 projects in the investment portfolio in parallel.

The firm was complex, with limited resources and project content. It was not possible to make large changes in the firm's infrastructure to overcome resource constraints. The case study proved the effectiveness for observing such procedures, which implied an increase in both the project's portfolio value and control over company resources.

Based on the theoretical background and completed ethnographic research, methodology was specified and a suitable company was chosen to verify it. The case study was a tool for the acknowledgement of the relevancy of set hypotheses. The company's top management statement confirmed that the decision for the project portfolio, which was designed using the methodology and/or software, made it possible to fulfil the set strategic goal (to prepare the set of requested investment projects) and strategic performance parameters (to reach NPV of the portfolio greater than 450,000 thousand CZK under given costs and resources). Based on the outputs of the case study, both hypotheses proved to be valid.

Such in-depth case-study research may help improve understanding and develop the capability for methods to link investment strategy with current operations. The growth of competencies of project managers and project teams along with strengthening weak elements of organisations and their management are also related to the above facts. Negotiated strategies in and across project portfolios as well as the sophisticated selection of projects into effective project portfolios (together with flexibility in transformations within such portfolios) can be strengthened by transparent methodology of portfolio modelling and evaluation using hardfacts and soft-facts. The methodology proved to be applicable in the SME environment.

On the basis of the outputs of this paper the authors recommend extending this research to a wider sample of SMEs and evaluate the results of managerial decision-making effectiveness in a strategic timeframe.

This paper was published with the support of the IGA2 IP 304015 internal grant agency program at the Faculty of Business Administration, University of Economics in Prague.

\section{References}

Aaltonen, P. (2010). Co-selection in R\&D Project Portfolio Management: Theory and Evidence (Doctoral Dissertation Series 2010/6). Helsinki University of Technology, Department of Industrial Engineering and Management, Espoo, Finland.

Aas, T. H., Breunig, K. J., \& Hydle, K. M. (2017). Exploring New Service Portfolio Management. International Journal of Innovation Management, 21(7), 1-31. https://doi.org/10.1142/S136391961750044X.

Archer, N., \& Ghasemzadeh, F. (1999). An integrated framework for portfolio selection. International Journal of Project Management, 17(4). https://doi.org/10.1016/S02637863(98)00032-5.

Aritua, B., Smith, N. J., \& Bower, D. A. (2009). Construction client multi-projects - A complex adaptive systems perspective. International 
Journal of Project Management, 27(1), 72-79. https://doi.org/10.1016/j.ijproman.2008.02.005.

Brester, C., Ryzhikov, I., \& Semenkin, E. (2017). Multi-objective Optimization Algorithms with the Island Metaheuristic for Effective Project Management Problem Solving. Organizacija, 50(4), 364-373. https://doi.org/10.1515/orga2017-0027.

Christiansen, J. K., \& Varnes, C. (2008). From models to practice: decision making at portfolio meetings. International Journal of Quality and Reliability Management, 25(1), 87-101. https://doi.org/10.1108/02656710810843603.

Coldrick, S., Longhurst, P., Ivey, P., \& Hannis, J. (2005). An R\&D options selection model for investment decisions, Technovation, 25, 185-193. https://doi.org/10.1016/S01664972(03)00099-3.

Cooper, R., Edgett, S., \& Kleinschmidt, E. (2001). Portfolio Management for New Products (2nd ed.). Cambridge, MA: Perseus Press.

Cooper, R., Edgett, S., \& Kleinschmidt, E. (2002). Optimizing the state-gate process: what best-practice companies do-II. Research Technology Management, 45(6), 43-49. https://doi.org/10.1080/08956308.2002.11671532.

Cooper, R., \& Edgett, S. (2003). Overcoming the crunch in resources for new product development. Research Technology Management, 46(3), 48-58. https://doi.org/10.1 080/08956308.2003.11671566.

Cooper, R., Edgett, S., \& Kleinschmidt, E. (2004). Benchmarking best NPD practices - II. Research Technology Management, 47(3), 5059. https://doi.org/10.1080/08956308.2004.116 71630.

Creswell, J. W. (2007). Qualitative Inquiry and Research Design: Choosing among Five Approaches (2nd ed.). Thousand Oaks, CA: Sage.

Dawidson, O. (2004). Expectations to be fulfilled by R\&D project portfolio management. In Proceedings of the EIASM Product development Management Conference (pp. 331-346). Dublin.

De Reyk, B., Grushka-Cockayne, Y., Lockett, M., Calderini, S. R., Moura, M., \& Sloper, A. (2005). The impact of project portfolio management on information technology projects. International Journal of Project Management, 23(7), 524-537. https://doi. org/10.1016/j.jproman.2005.02.003.

Engwall, M., \& Jerbrant, A. (2003). The resource allocation syndrome: the prime challenge of multi project management? International Journal of Project Management, 21, 403-409. https://doi.org/10.1016/S02637863(02)00113-8.

ERNST \& YOUNG. (2013). Průzkum řízení projektů v ČR a SR 2013.

EIRMA, European Industrial Research Management Institute. (1995). Evaluation of $R \& D$ Projects [Working group reports, Report No. 47]. Paris: ERIMA.

Fahrni, P., \& Späting, M. (1990). An application oriented guide to $R \& D$ project selection and evaluation methods. $R \& D$ Management, 20(2), 155-171. https://doi. org/10.1111/j.1467-9310.1990.tb00693.x.

Fotr, J., \& Hnilica, J. (2014). Aplikovaná analýza rizika ve finančním managementu a investičním rozhodování (2nd ed.). Praha: Grada Publishing.

Fotr, J., \& Souček, I. (2015). Tvorba a rízení portfolia projektů. Praha: Grada Publishing.

Fotr, J., Švecová, L., Hrůzová, H., \& Richter, J. (2010). Manažerské rozhodování. Postupy, metody a nástroje. Praha: Ekopress.

Fotr, J., Vacík, E., Špaček, M., \& Souček, I. (2015). Scenarios, their concept, elaboration and application. Baltic Journal of Management, 10(1), 73-97. https://doi.org/10.1108/BJM-012014-0004.

Gassmann, O., \& Reepmeyer, G. (2005). Organizing Pharmaceutical Innovation: From Science Based Knowledge Creators to Drug Oriented Knowledge Brokers. Creativity and Innovation Management, 14(3), 233-246. https:// doi.org/10.1111/j.1467-8691.2005.00344.x.

Ghasemzadeh, F., \& Archer, N. (2000). Project selection through decision support. Decision Support System, 29(1), 73-78. https://doi.org/10.1016/S0167-9236(00)00065-8.

Hauser, J. R., \& Zettelmeyer, F. (1997). Metrics to evaluate R,D\&E. Research Technology Management, 40(4), 32-38. https://doi.org/10.1080/08956308.1997.11671140.

IPMA $®$, International Project Management Association. (2015). Individual Competence Baseline for Project, Programme and Portfolio Management. Version 4.0. Nijkerk, The Netherlands.

Joubert, F. J., \& Pretorius, L. (2017). Using Monte Carlo Simulation to Create a Ranked Check List of Risks in a Portfolio of Railway Construction Projects. South African Journal of Industrial Engineering, 28(2), 133-148. https:// dx.doi.org/10.7166/28-2-1604. 
Killen, C. P., Hunt, R. A., \& Kleinschmidt, E. J. (2008). Project portfolio management for product innovation. International Journal of Quality \& Reliability Management, 25(1), 25-38. https://doi.org/10.1108/02656710810843559.

Kock, A., \& Gemünden, H. G. (2016). Antecedents to Decision-Making Quality and Agility in Innovation Portfolio Management. Journal of Product Innovation Management, 33(6), 670-686. https://doi.org/10.1111/ jpim.12336.

Korotin, V., Popov, V., Tolokonsky, A., Islamov, R., \& Ulchenkov, A. (2017). A multicriteria approach to selecting an optimal portfolio of refinery upgrade projects under margin and tax regime uncertainty. Omega, 72, 50-58. https://doi.org/10.1016/j.omega.2016.11.003.

Kunz, C. (2007). Strategisches Multiprojektmanagement (2nd ed.). Wiesbaden: Deutscher Universitäts-Verlag.

Lawson, C. P., Longhurst, P. J., \& Ivey, P. C. (2006). The application of a new research and development project selection model in SMEs. Technovation, 26(2), 242-250. https://doi. org/10.1016/j.technovation.2004.07.017.

Liu, Y., \& Liu, Y. K. (2017). Distributionally robust fuzzy project portfolio optimization problem with interactive returns. Applied Soft Computing, 56, 655-668. https://doi. org/10.1016/j.asoc.2016.09.022.

Lomnitz, G. (2004). Multiprojektmanagement. Projekte erfolgreich planen, vernetzen und steuern (2nd ed.). Frankfurt: Redline Wirtschaft.

Lukesch, C. J. (2000). Umfassendes Projektportfoliomanagement in Dienstleistungskonzernen am Beispiel eines grossen, international operierenden Versicherungsunternehmens. (Doctoral Dissertation No. 13710). Zürich: ETH.

Martinsuo, M., \& Lehtonen, P. (2007). Role of single-project management in achieving portfolio management efficiency. International Journal of Project Management, 25(1), 56-65. https://doi.org/10.1016/j.ijproman.2006.04.002.

Martinsuo, M. (2013). Project portfolio management in practice and in context. International Journal of Project Management, 31, 794-803. https://doi.org/10.1016/j. ijproman.2012.10.013.

Mathews, S. (2009). Valuing risky projects with real options. Research-Technology Management, 52(5), 32-41. https://doi.org/10.1 080/08956308.2009.11657587.
Miguel, P. A. C. (2006). Technology Management for the Global Future. PICMET, 6, 2724-2731.

Mohagheghi, V., Mousavi, S. M., \& Vahdani, B. (2015). A New Optimization Model for Project Portfolio Selection under Interval-Valued Fuzzy Environment. Arabian Journal for Science and Engineering, 40(11), 3351-3361. https://doi. org/10.1007/s13369-015-1779-6.

Mohagheghi, V., Mousavi, S. M., Vahdani, B., \& Shahriari, M. R. (2017). R\&D project evaluation and project portfolio selection by a new interval type- 2 fuzzy optimization approach. Neural Computing \& Applications, 28(12), 3869-3888. https://doi.org/10.1007/ s00521-016-2262-3.

Pérez, O. R., Watts, D., \& Flores, Y. (2018). Planning in a changing environment: Applications of portfolio optimisation to deal with risk in the electricity sector. Renewable \& Sustainable Energy Reviews, 82(3), 3808-3823. https://doi.org/10.1016/j.rser.2017.10.089.

Poh, K. L., Ang, B. W., \& Bai, F. (2001). A comparative analysis of $R \& D$ project evaluation methods. $R \& D$ Management, 31(1), 63-75. https://doi.org/10.1111/14679310.00197.

PMBOK, Project Management Institute. (2013). A Guide to the Project Management Body of Knowledge (5th ed.).

PRINCE2. (2017). Managing Successful Projects with PRINCE2® (1st ed.). Second Impression, AXELOS.

Qiang, M. (2017). Research on the Construction of Energy Project Portfolio Management Process System. Agro Food Industry Hi-Tech, 28(3), 249-253.

Ringuest, J., Graves S., \& Case, R. H. (1999). Formulating R\&D portfolios that accounts for risk. Research Technology Management, 42(6), 40-43. https://doi.org/10.1 080/08956308.1999.11671317.

Sanwal, A. (2007). Optimizing Corporate Portfolio Management: Aligning Investment Proposals with Organizational Strategy. Hoboken: John Wiley \& Sons.

Seidl, J. (2011). Multiprojektmanagement. Heidelberg: Springler.

Shah, R., \& Jammalamadaka, P. R. (2017). Optimal Portfolio Strategy for Risk Management in Toll Road Forecasts and Investments. Transportation Research Record: Journal of the Transportation Research Board, 2670, 83-94. https://doi.org/10.3141/2670-11. 
Spradlin, C., \& Kutoloski, D. (1999). Actionoriented portfolio management. Research Technology Management, 42(2), 26-32. https:// doi.org/10.1080/08956308.1999.11671270.

Steinle, C., Eßeling, V., \& Mach, K. (2010). Entwicklung einer Konzeption zur Priorisierung und Selektion von Projekten im Rahmen des Projektportfolio-Managements. In C. Steinle, V. Eßeling, \& T. Eichenberg (Eds.), Handbuch Multiprojektmanagement. Projekte Erfolgreich strukturieren und steuern (2nd ed.) (pp. 159-172). Berlin: Erich Schmidt Verlag.

Vacík, E., \& Kracík, L. (2015). Multiprojektování a priorizace projektů $\checkmark$ inovativních podnicích. Ekonomický časopis, 63(1), 72-94.

Verbano, C., \& Nosella, A. (2010). Addressing R\&D investment decisions: a cross analysis of R\&D project selection methods. European Journal of Innovation Management, 13(3), 355-379. https://doi. org/10.1108/14601061011060166.

Wideman, R. M. (2005). Foreword. In H. A. Levine (Ed.), Project portfolio management: a practical guide to selecting projects, managing portfolios, and maximizing benefits. San Francisco, CA: John Wiley and Sons, Inc.

Wu, W., Dandy, G. C., Maier, H. R., Maheepala, S., Marchi, A., \& Mirza, F. (2017). Identification of Optimal Water Supply Portfolios for a Major City. Journal of Water Resources Planning and Management, 143(9).

Xu, W., Liu, G., Li, H., \& Luo, W. (2017). A Study on Project Portfolio Models with Skewness Risk and Staffing. International Journal of Fuzzy Systems, 19(6), 2033-2047. https://doi.org/10.1007/s40815-017-0295-0.
Yong-Hong, S., Jian, M., Zhi-Ping, F., \& Jun, W. (2008). A group decision support approach to evaluate experts for R\&D project selection. IEEE Transactions on Engineering Management, 56(1), 158-170. https://doi. org/10.1109/TEM.2007.912934.

doc. Ing. Emil Vacík, Ph.D. University of West Bohemia, Plzeň Faculty of Economics

Department of Finance and Accounting Czech Republic vacik@kfu.zcu.cz

doc. Ing. Miroslav Špaček, Ph.D., MBA University of Economics, Prague Faculty of Business Administration Department of Entrepreneurship Czech Republic miroslav.spacek@vse.cz

prof. Ing. Jiří Fotr, CSc. University of Economics, Prague Faculty of Business Administration Department of Entrepreneurship Czech Republic fotr@vse.cz

\section{Diplom-Betriebswirt (BA) Lukáš Kracík, M.Sc., Ph.D. University of West Bohemia, Plzeň Faculty of Economics Department of Finance and Accounting Czech Republic lukas.kracik@gmail.com}




\title{
Abstract
}

\section{PROJECT PORTFOLIO OPTIMIZATION AS A PART OF STRATEGY \\ IMPLEMENTATION PROCESS IN SMALL AND MEDIUM-SIZED ENTERPRISES: A METHODOLOGY OFTHE SELECTION OF PROJECTS WITH THE AIM TO BALANCE STRATEGY, RISK AND PERFORMANCE}

\author{
Emil Vacík, Miroslav Špaček, Jiří Fotr, Lukáš Kracík
}

This paper presents an improved managerial approach to project portfolio development using software optimization tools. A review of literature revealed a gap formed by the lack of either an established approach or a normative model of how to develop portfolios in SMEs. To bridge this gap, this paper is based on topical information and offers a method that supports decision makers in their choice of the most suitable project portfolio. This method can be implemented by the use of a simulation software tool for project portfolio optimization while considering constraints and conformity with corporate strategy. The authors conclude that the foundation of success is to formulate optimum portfolios, the configurations of which reflect all key strategic parameters. Moreover, it must be feasible to implement such a portfolio in the environment of SMEs within disposable firm resources and consider identifiable risks upon the selection of the effective project portfolio. One chosen case study evidenced the viability of this approach. The approach to project portfolio optimization discussed in this paper shows the effectiveness of the selected methodology for project portfolio optimization that in turn significantly contributes to meeting strategic goals and thus an increase in company performance and shareholders' value. The use of a common software tool together with the right access to data collection and processing allows managers to make better decisions for the effective future allocation of resources over the chosen project portfolio.

Key Words: Strategy, project portfolio management, project, programme, portfolio optimization, efficient frontier, SME.

JEL Classification: O21, O22, 032.

DOI: 10.15240/tul/001/2018-3-007 